\title{
"HOW I GAVE BIRTH" (AND WHY I AM WRITING ABOUT IT): WOMEN'S NARRATIVES OF FIRST CHILDBIRTH EXPERIENCES FROM INTERNET PUBLICATIONS
}

\author{
Natalia Gramatchikova \\ Senior Research Fellow \\ Center of History of Literature, Institute of History and Archeology \\ Ural Branch of the Russian Academy of Sciences, Russia \\ n.gramatchikova@gmail.com
}

\begin{abstract}
This article is dedicated to the research of the structures and meaningful concepts of women's stories about the first childbirth, obtained by their personal experience in the governmental obstetrical system. Narratives of childbirth contain complex knowledge including description of physiological and emotional reactions and characteristics of Russian maternal initiation practices, culminating in the maternity ward. Similar narratives posted on social network and web pages of family portals reveal elements of hypertext and several leading factors of their origin, such as being the consolidation of a new identity through a retrospective autobiographical story, joining the community of motherhood, broadcasting experience to its new members, etc.
\end{abstract}

Keywords: childbirth, family, maternity hospital, narrative, pain, personal history, repressiveness, women in labor

\section{INTRODUCTION}

The first draft of this research, presented as a lecture in Moscow at the 3rd National Russian Congress of Folklore in 2014, received a critical response unexpected for the author. The criticism partially referred to the selection of material and the author's approach to it. Other replies repudiated the very interpretation of narratives on childbirth as a story of the existing discriminating practices, referring them to the irrelevant Soviet past. Meanwhile, the recent (at that time) empirical repeated experience of the author (who has had four children through caesarean section) as well as the collected first-hand materials witnessed of the inverse. 
In Russia, for a couple of past decades, research on motherhood and childhood has developed in several different directions. Folklorists, ethnographers and ethnolinguists collected and processed field materials on the transformation of traditional birth rites, which remains beyond the scope of this article. Anthropologists, sociologists, and historians formed an interdisciplinary field of research in the context of humanization of medicine and bioethics. Gender and feminist studies have driven this 'new wave' of the anthropology of motherhood development. The bibliography of such studies includes hundreds of Russian-language publications. However, this amount continues to lag behind its foreign counterparts.

The popularity of works such as Birth in Four Cultures by Brigitte Jordan (1978) and Human Birth: An Evolutionary Perspective (Foundations of Human Behavior) by Wenda R. Trevathan (1987) showed signs of understanding the necessity to humanize birth and to pay attention to the emotional condition of women in labor. The first collection of articles devoted to pregnancy and births, seen from an intercultural point of view, Anthropology of Human Birth, edited by Margarita A. Kay (1982), and Ethnography of Fertility and Birth, edited by Carol P. MacCormack (1982) were based on the approach suggested by Jordan. ${ }^{1}$ Similar Russian studies developed with some delay due to a different social and academic context. There were a few works on childbirth written by folklorists and anthropologists in the 1990s, while the thesis of birth ritualism preservation in the state establishments sounded as a forward-looking one (Belousova 1999). However, in the past 15 years, Russian studies of the obstetrical system, motherhood and childhood were carried out by researchers of virtually all disciplines of the humanities and social sciences. Feminist values are actualized in these studies.

Folklorists indicate that current childbirth rites show signs of transformation in female knowledge and behaviors, characteristic of peasant and metropolitan culture (Shchepanskaia 1999; Nekliudov 2001; Olson \& Adonyeva 2012). Historians study material related to motherhood, pregnancy, etc., based on the data of various social strata of different epochs (Mukhina \& Pushkareva 2012; Pushkareva \& Mitsiuk 2015; Mitsiuk \& Pokusaeva 2016). Sociologists were among the first researchers to record the problem of a trust gap, publishing a collection of articles in 2009, under the heading Health and Trust: A Gender Approach to Reproductive Medicine (Zdravomyslova \& Temkina 2009), including works by researchers who continue to study these issues (Elena Zdravomyslova, Anna Temkina, Olga Brednikova, Ekaterina Borozdina, Olga Tkach, etc.). Voluminous works on obstetric aggression are in high demand not only among the researchers but also among the professional medical community (Mikhel' 2017; Radzinski 2017). ${ }^{2}$ 
A survey of Russian and foreign sources that covers the topic of obstetrics and childbirth has become the topic of several historiographical articles that demonstrate the rapidly accumulating package of research (Nartova 2016; Pushkareva \& Mitsiuk 2017; Kuksa 2019).

The greater part of the aforementioned studies used archival data, interviews, and ego-documents as their foundational materials. However, in the past two decades women began to express their labor experiences in a new way, through posts on the social media, forums, and blogs. This new type of expression has created new research frames. Thus, the narrative study of the structures and objectives of the female childbirth stories, derived from sites and forums offering a space for the exchange of personal experiences on the subject, proves to be a valuable philological task (Raynor 2005), especially considering the fact that the Russian-language sector of the Internet has yet to be properly examined.

\section{MATERIAL AND PROBLEMS OF INVESTIGATION}

A woman can never be fully prepared for childbirth. Birth, like death, can encroach unexpectedly. During childbirth, a woman teeters on the boundary between life and death, only to return with the title of Mother. Although only the first birth is socially complaisant, it is precisely the first birth that affirms the new stage of family life and transforms partners into parents, in accordance with relatives' expectations.

The first birth is normative for the obstetrical system, revealing the condition of the perinatal culture, and it is important for the examination of alternative childbirth methods (birth in water, at home, etc.). A complete picture of a present-day birth can only be attained by analyzing all birth methods, including through the socialized medical system, at a private paid clinic, at home, by caesarean section, second and further births, as well as childbirth with complications. However, the first childbirth experience is the litmus test for the condition of the obstetrical system, since it occurs without the woman seeking an option of particular comfort or safety.

The source of the material collected for analysis was Russian-speaking women writing about their first personal childbirth experiences in the governmental obstetrical system, on internet sites and forums devoted to motherhood and childbirth. The greater portion of texts I obtained for the analysis were collected from the websites 7ya.ru, Дети@Mail.ru, and Kid.ru as well as the VK.com social network (the group Stories of childbirth. How I gave birth. Birth of my child). The list of sites is extensive, but texts analyzed for my purposes 
are definitively illustrative. ${ }^{3}$ The timeframe covers the last 20 years, since some texts were written with considerable time lags, because often the author's decision to speak about her first birth was a direct result of the experience of the second and further births.

Using these materials, I focused on the following questions:

1) What is the structure of the narrative initiated by the woman herself and not by the interviewer?

2) What is the narrator's position in these posts? In what manner does the woman's position enter into the medical prenatal system? How does she evaluate the system and how does she communicate this evaluation to the community? What moments of her childbirth experience are reflected as traumatic?

3) What are the objectives and meanings found in the messages in internet texts? Are these messages caused by the desire to remember and share experiences? Are they meant for cheering up, warning or scaring? What enquiries of the audience do these messages answer?

\section{INTERNET NARRATIVES OF CHILDBIRTH: GENERAL REMARKS}

Internet narratives differ from those obtained by interviewing, performing the function of autobiographical communication and horizontal translation of experience. Verbal communication is highly significant in Russian culture in general and, as a result, also valued in current birth rituals (see also Belousova 1999), causing us to pay particular attention to these aspects in such stories.

It is difficult to impose typology on these narratives because of differences in such factors as education, health, financial status, social status, places of residence, proximity of spouse and other close relatives and their relationships as well as the level of skills and professionalism of medical workers. Nevertheless, from the philological point of view, narratives of childbirth often contain features peculiar to supertexts (Toporov 1995 [1971]: 275) because they contain uniform structural parts, created in the general narrative model (which is connected to physiological stages of birth and to realities of birth aid in maternity wards). A certain genre model was assimilated while reading similar stories, but before posting their own. "I have read a lot of stories about childbirth and thought that when it finally happens to me, I will write about my experience..." (Marchenkova n.d.). On the other hand, narratives are often formed in an oral manner, then later posted on the Internet. 
Why did I write about this? Because I have an acquaintance who wants to have a baby, but she's afraid. She asked me to tell her how it was with me. After our talk, I had the idea to share my story with others. (Nastia 2019)

Characteristic of these types of narratives is the high concentration of numbers included: the expected delivery date, the time the contractions begin, their length and how often they occur, measurement of dilation of the cervix, what time the water breaks, and how long is the time between water breaking and birth, length of the labor, weight and length of the newborn, and even the number of doctors in the delivery room ("There were a total of seven medical workers plus Nadia and me. That had to mean something" (bjbj2 n.d.)), etc. The condition of consciousness changes time perception: a slow-motion effect exists during the labor and for some time after birth: "So ten days ago today, my son came into this world" (Marchenkova n.d.); a few hours of contractions seems comparable to weeks of pregnancy: "A 42-week pregnancy and birthing in ten hours" (Evgeniia 2012).

However, colors and smells are not fixated as clearly in the memories (with the exception of the memory of a milk-like smell of the newborn or a long-term complex negative feeling: “...The pain is making me sick to my stomach. With every contraction, I was with my 'white friend' (by the way, to make matters worse, it was broken and stunk all night)" (Mashinova 2020)); and tactile feelings are most often expressed as painful. The level of acuity of words and actions and not only their own words, but those of their roommates, of the doctors and midwives, etc., is very high. ${ }^{4}$

For the most part, the internet audiences of childbirth narratives are female, usually cooperative with the medical system. Their firsthand experiences demonstrate that the governmental obstetric system is most loyal to women who "do everything correctly": register the pregnancy in a timely manner, are young, married, with a desire to give birth at the maternity hospital and are open to the recommendations and actions of the medical personnel there.

Most of the authors of the narratives consider their first birth positive and favorable overall; the titles of their stories reveal that in retrospect, they often accentuate the humorous side of their personal story. It is worthwhile to note that the narratives we studied do not in any manner claim to cover the full extent of childbirth stories. Rather, they are selections demonstrating our basic premise (considering it would be impossible to reproduce the population while overlooking the well-being of the first-time mother's birthing experience). Close concomitants in the material I consider here are stories of aggression and abuse during childbirth, medical neglect, stillborn cases, etc. The boundary between the 'good' and 'bad' is rather fluid, and in every story, topics of (dis)trust and 
aggression emerge, though they are not always acknowledged by the narrators themselves.

\section{THE MAIN NARRATIVE ELEMENTS}

Next, the parts of the childbirth narrative and their semantic content are considered. Highlighting the successive elements of the narrative structure associated with the physiological stages of delivery and logistics of the maternity hospital, particularly important themes occurring within each department related to that stage of childbirth (the emergency room, the labor and delivery room, etc.) are discussed. Reference points of the childbirth story are so tenacious that, even if the mother did not have a particular experience, they will still note their absence typically with relief, since the marker was a connection to unpleasant aspects of childbirth:

For ten years, I listened to other people's stories about childbirth. ... Each story was worse than the one before it ... But I still wanted a baby so bad, and I was ready to be the hero... when my long-awaited baby began to form within me, my fears also grew ... I'll die from unbearable pain during labor ... the rude nurse will ignore my suffering without even a drop of sympathy ... I will be torn during delivery ... my newborn will be dropped on the cement floor. (Elena 2007)

\section{Introduction: An unexpected inception}

The introduction to the story of childbirth is often a brief narrative about how the pregnancy went. The beginning of this birthing process is almost always described as unexpected. Everything that happened immediately before the onset of labor is imprinted in the memory as the last moments of peaceful life with its coziness, comfort, and tastes: many women remember what they ate just before the start of childbirth: bread with milk, apple and plum pie; ice cream, nuts, peaches, cherries.

Here, the qualities that a woman demonstrates in her normal status and social environment are important. Rational reasoning and planning can be positioned as leading features, and this style will project throughout the narrative from pregnancy to childbirth: "I'm used to planning important events in my life. And child planning was no exception ... I never wanted surprises, especially during pregnancy" (Matiz 2015). ${ }^{5}$ In the concept of labor, the woman 
in the analyzed texts is active, she has a respected status in the family, including among relatives of the older generation: "My mother-in-law was really worried about me and talked me into staying at home so that labor didn't start outside, but I went everywhere with my husband, walked in the evening" (Marina 2008). "I started to shout out commands. I'm in labor, take me to the hospital..." (Marchenkova n.d.).

The broader context, in which the date of birth was included in the preparatory period, literally collapses at the onset of labor: "April 20th... It's Hitler's birthday... I wanted to give birth already" (Calypso 2010). The comic relief contained in this message makes it clear to the audience how the measurement of time and the idea of good days vary for a woman tired of waiting.

\section{Emergency department of the maternity hospital:}

\section{Entrance to the 'other world'}

The initial part of the stories about childbirth, as a rule, contains internally opposed episodes: the inevitable bustle of arriving to the emergency room and being admitted to the maternity hospital. No matter what titles the expectant mother has taken on heretofore ('the planner', 'the organizer of the nest' and even 'the silly friend'), she makes the decision that it is time to go, and communicates this decision to the family, thus maintaining an accentuated subjectivity. However, even when admitted to the maternity hospital, a woman's activity is threatened in the face of strict rules in which the 'necessary' and 'required', including personal belongings, are determined by the medical staff.

From the moment of the woman's admittance to the maternity ward, her narrative expresses the framework of a journey to the 'other world'6, with features similar to a travelogue guide. The following scheme is well-known: farewell to your spouse (or any other person who came with you) - enema - shower - official clothes. The narrative marker of this new world is the maternity gown ("They put an UGLY gown on me ... and gave me an ugly robe too (of course, I'm not worried about THAT, but it just wasn't possible not to mention IT" (Jane 2006)), shaving ("Hungry, scared, took off my clothes and took a shower. The water wasn't hot enough, a hunk of household soap, a blunt razor..." (Zlato-serebro 2009)), and an enema ("I never remember in my whole life I had an enema, and I came out of the toilet with the feeling that the worst is behind me" (Olga 2001)). Even just one familiar person on the staff has the potential to change the woman's perspective immensely. 
They gave me a shirt to change into, put in the enema, and sent me to wash off in the shower. I love showers, even while in labor - even washed my hair while I was in there - for that I got a lecture from the nurse. Went to my room - where my friend, Nadiusha was happy to see me, maybe this won't be so bad. (bjbj2 n.d.)

Each of these three elements - the gown, shaving, and the enema, are connected to the loss of the status, reducing the expectant mother to the lowest rank in societal hierarchy with the loss of property and even gender and age attributes (with the act of shaving). Nevertheless, most narrators are simply mundane about these procedures: "Asked me if I agreed to an enema. Sure. It wasn't as awful as I thought it would be...." (Shepka n.d.), but often this attitude is paid for by a contrasting difficult experience:

The doctor put his finger up my uterus. I let out a scream in pain not expecting it. Doctor says, how do you expect to give birth? Changed into the maternity gown. Enema. I was worried about it, but it wasn't as bad as I thought it would be. (Elisaveta777 2015)

Let us note the obvious associative connections and meanings that are embedded in these three things, because they are actualized in the narratives. The maternity gown, especially since birth and death are deeply related to each other, can be considered as the antithesis of mortal clothing. The clothing of the deceased has to be clean, new, and belong to them; in contrast, the typical maternity gown is used, foreign, and, although sterile, visually impure. The impression of the gown is further aggregated when given menstrual pads made from rags (Olga 2001). Shaving of the genitals and having an enema are the first formidable threats of the liminal state, destroying intimacy and producing shame. The procedure for setting up an enema during contractions is painful and is reflected narratively with a lack of trust. Many women make attempts to avoid the procedure, claiming that they have not eaten for many hours, or have already taken laxatives at home, but usually these tricks are fruitless. The topic of trust deficit increases as it is supported by further deprivation: "When they admitted me, they couldn't believe my contractions were so close together and so long ... My husband called. And they made me turn off my phone" (Marina 2008).

The commanding intonations of the medical staff, noticed in the texts of maternity hospitals, further disidentify the woman with her own body, adding to the confusion caused by a new bodily experience. Paradoxically, high-quality theoretical training in the courses of expectant mothers often determines the deep discursive conflict that a woman who is accustomed to listening to her 
body goes through, juxtaposed with the fact that the stages of her birth are determined by the medical staff as follows: from "you aren't even screaming" to "okay, time to put you in stirrups" (see, e.g., Petrova 2009: 354, 361). Only a few people insist on the correctness of their own feelings and demand changes in the birth plan, making sure to note this in their stories: "I told them off", "I went up to her and hit the desk", "I barked out my demands", and so on. It is important to remember that one of the functions of the autobiographical narrative is to serve as a framework for self-identity, so these statements can also be interpreted as rhetorical decorations that allow the woman in labor to retrospectively assert their own subjectivity, comparable in significance to the will of the medical staff. Thus, in women's narratives, one can find a struggle for subjectivity developing in spite of procedural realities that lower the status, where the author manages to show it at least by rhetorical means.

\section{Prenatal ward}

The hours of labor contractions begin in the prenatal ward. From the outside, they look like an inactive waiting, but from the inside, from the position of the narrator, this is the most dramatic, seemingly endless stage, through which a woman passes in pain and subjective loneliness, experiencing a loss of control over the body and the complexity of interaction with the hospital staff.

\section{Birth pain: Self-encounter and scenario collapse}

The main issue of this narrative stage is the description of the growing pain and associated fear. It is important to note that most of all pregnant women are afraid of facing the pain. They try to clarify its nature and strength through questions in the comments; thus, the request for a description of labor pain is supported on both sides: narrators try to find words for the experienced feelings resorting, mostly, not to metaphor, but to 'increasing the volume' through using all upper case letters and pedaling the main meaning of words, and the audience greedily listens to this.

I was skeptical about women who YELL while in labor and told myself the pain is bearable and you can grit your teeth and bear it ... Pain is something you CAN BEAR ... I was even able to live through THE UNBEARABLE!!! It's torture... I SCREAMED bloody murder for the whole 5-6 hours. And it wasn't because I don't have any self-control or because I'm a brat or whatever else - THAT WAS HOW I REALLY FELT. (Jane 2006) 
Birth pain, revealing the failure of speculative schemes, turns out to be the locus communis of eternal maternal initiation, opening up the possibility of identification with any of the mothers who lived on our planet. ${ }^{7}$ Pain becomes an end-to-end plot of 'women's genealogy', preserving its ambivalent nature:

I had one persistent thought: 'These people are crazy. My mom. My grandma. All the women who've ever given birth to a second or even a third child, crazy! It's just not normal - consciously come here a second time. It's insane. Schizophrenia. Sadomasochism.' (Shepka n.d.)

Pain also sets the value of a child who is "worth the pain".

It is at the stage of labor pain that unexpected behavior occurs most often. In the experience of pain, a woman meets a hitherto hidden side of her physicality, sensitivity, and will. It can be cautiously said that women who are characterized by high standards and demands on themselves and others are less likely to show satisfaction with how they are going through the birth process. Markers of a disappointing discrepancy with the intended scenario are the words: "Everything went wrong", "I didn't want it to be like that and could have never imagined it would be like that".

The unpredictability of childbirth, which doctors often talk about, is reflected in the coexistence of paired narrative scenarios (natural childbirth and caesarean section), among which one - emergency caesarean section - occurs directly during childbirth and, therefore, does not allow mental preparation for it in advance. So, it is an emergency caesarean that is understood by women retrospectively, over a long period of time. Without specifically focusing on this story, I note that the narrators offer several techniques for dealing with the unexpected that has invaded their life: "You have to find strength within yourself to defeat these negative emotions. You should understand that it was the ONLY way to save your baby's life. Consider it your sacrifice for your child's welfare" (Kasparova 2002). Although physical recovery after operative childbirth is imminent, the plot continues to develop, because it is the mother who feels responsible for the appearance of the 'caesarean', whose beginning of life in public opinion is considered less successful than in natural childbirth.

Therefore, facing a birth pain often occurs in stories about the birth moment that runs the script change due to the initiative of relatives worried about the state of expectant mothers. Evidence of this perception of pain and its influence on what happens in childbirth is abundant (Margo 2009, etc.). 


\section{Medical staff: On whose side?}

With pronounced discursivity, childbirth stories are deeply personal, where individual memory is maintained conventionally: the condition 'write only about your experience', not including the stories of your wardmates, is displayed on many internet sites and activated in the comments. A kind of maternity travelogue from the beginning of labor to delivery is marked by a search for allies and helpers among the staff of the hospital.

In traditional culture, the entire burden of accompanying and symbolically filling the birth process lies with the midwife. Although Ekaterina Belousova (1999) considers obstetricians as direct heirs of midwives, there are clear differences. In contrast to the midwife who accompanies a woman during childbirth from the beginning to the end, doctors are distanced from women in labor, often anonymous. Teams change depending on the order of duty, while the woman continues to give birth. Often women in childbirth do not know the names of doctors and midwives, sometimes giving rationality to these arguments: "In childbirth, apparently, euphoria and encephalopathy occur, because I asked the doctor's last name several times, but I did not remember" (Akishina 2005). Women's attempts to establish personal contact with doctors are not always successful, but remarkable for their constancy. In texts, they are mostly presented as women's initiative, choosing a personal, non-systemic style of relations.

The need for a person nearby is noted by many women in childbirth. "The midwife came in and sat down beside me, rubbed my stomach with her cool, gentle hand, and believe it or not, I felt so much better. As soon as she left, the pain and fear took over again" (Zlato-serebro 2009); "After they came in to give me a shot to sleep, I hugged the nurse, and held her tight and then was able to make it until they could give me anesthetics!" (Kozupitsa 2009)

In the statements of doctors, women also highlight not the physiology of pain, but its moral value. Their conversations with doctors describe pain as an inevitable 'redemption': "The doctor... gave me a strict judgmental look: 'Ok, get ready for some terrible pain. Unbearable pain. And no kind of pain relievers are going to help you. So get ready!"' (Olga 2001). At this stage, pity turns into something that hinders, depriving you of strength: "Ladies, my best advice: don't feel sorry for yourself during labor!! It will only make things worse. It's really hard to push when it just makes the pain worse" (Margo 2009).

Thus, if the severity (but not rudeness) of the staff in these moments in general is accepted by the expectant mother as inevitable in an emergency situation, the medical manipulations are often assessed by mothers as physically unnatural for her (such as check-ups on an examination chair during 
a contraction). On the other hand, doctors, taking the 'side of the pain', protect the woman and child from irrational actions the woman in labor could take if she were in complete control, driven only by the desire to get rid of the pain. In this case, women are grateful to doctors after the fact for providing more acceptable conditions:

All of a sudden, I had a terrible pain in my abdomen, unbearable pain, like I had a boiler inside me; everything is heating up and wants to come out. I'm screaming, they check my cervix. Yes, sweetie, they said, you would have given birth on your back, would have torn terribly. You should be thankful that we practice vertical birthing. (Oksana 2005)

\section{Medical staff: Roles and functions}

In the narratives of women who gave birth, the roles of midwives, gynecological surgeons, and anesthesiologists are different. ${ }^{8}$ Obstetric nurses-midwives are often referred to either as a source of verbal aggression or, conversely, with gratitude. Surgeons have a radical influence on the future of maternal and female destiny. The medical staff also inherits the prophetic functions of midwives, who, according to traditional beliefs, can reveal the future fate of the child. For example, in one narrative, a nurse delivering twins suddenly mentions that she is also a twin, and her sister died in childbirth; in turn only one of the twins delivered by the woman in labor survives, the second dying due to an error by the medical staff. The medical staff themselves have a number of professional tips that they share with incoming patients: "The birth will go as the enema goes!" (Liudmila n.d.) Even agreements with doctors can be filled with performative power, because they occur in a special place and at a special time (Calypso 2010).

In women's stories, anesthesiologists are singled out in a special group taken that the measure of pain and the fullness of a woman's presence at her own birth (concerning the epidural or general anesthesia) depend on them. Communication with the patient is an important part of their official duties; they know the woman in labor by name and build quite long dialogues with her. Anesthesiologists, more often than others, become involved in stories about doctors being lightly flirtatious: after all, the meeting with them often occurs in a 'normal' state and not during labor. They are joked with, needled, begged, reasoned with; they use a wide range of rhetorical reactions.

Examples of aggression (often verbal) on the part of women in childbirth in their narratives are expected to be less than the opposite, but they occur. As 
a rule, their existence is justified for the narrator by subsequent erroneous or rude actions of the doctors; i.e., the motivation has a prospective, anticipating further conflict: ${ }^{9}$

I felt like I was being torn apart from the inside out. I screamed. She [the midwife] says:

'What are you yelling at?'

And I scream 'GO TO HEELLL!'

'Sure, thank you'.

And she leaves. (Kukusikii 2019)

In fact, the woman and the doctors are fighting against her organism, nature itself, which at the moment the woman is aware of as beyond her control. The doctors fight and support a woman's body at the same moment. ${ }^{10}$ In this case, removing the obstacle with actions and words of a frightened woman in labor is quite logical, but after some injections her ability to maintain self-control sharply decreases, which only increases the alienation from her own body and distrust of the staff.

After neutralizing the nervous patient with injections, doctors are forced to mobilize her will with more aggressive and louder communication.

Then they gave me a shot to go to sleep, but it didn't help the pain, I just dropped off to sleep between the contractions, but when the contractions started, I'd wake up again. Thanks to the midwife, she really helped me during that time, she came in every once in a while and talked to me really sternly, so that I would wake up, and look at her ... She's the only one I remember. Who else was there? I have no idea. The only thing I remember is her big gray eyes and her stern voice! (Ismailova 2012)

Thus, in the current state of affairs, there is a vicious cycle: not trusting a woman burdened by her 'nerves', doctors try to eliminate the interfering factor, and then they have to use ruder, more aggressive and commanding methods to motivate her to cooperate. In the last fragment, the strictness of the labor nurse is welcomed, since it promotes concentration and serves as a beacon to get out of pain when the usual means of control and interaction are not available due to a difficult physical condition.

Women in labor especially remember the words and actions of the medical staff, which contrast strikingly with their condition, and emphasize the routine nature of what is happening for doctors. These memories are also ambivalent: they are defiantly dissonant to the experience of women in labor, exhibiting a complete lack of empathy, but they also serve as a kind of anchor in relation 
to the everyday world, from which the woman in childbirth is temporarily separated, but whose steadfastness supports confidence in their own successful outcome:

The medical team was having a good time laughing at me. Irina, don't do that. Breathe... Irina... don't groan, breathe... and later behind the maternity hospital, the grass was burning and the firemen came... the whole medical team came in my room so they could look out the window and watch how the young men put out the fire... The fire was in me, I was burning up, I was shaking from pain... I was about to eat the bed, I was in so much pain... and all the while they were distracted by what was going on outside my window, making comments about the handsome firemen, laughing, and in between all of this every once in a while telling me, Ira, push... (Calypso 2010)

\section{Responsibility and guilt in a crisis of subjectivity}

In the part of the stories related to the prenatal ward, doctors are represented as episodic and unfaithful allies of women in labor because contact with them is fickle, their actions are not predictable for women suffering from labor pain, their intonations range from strict and even rude to routine-empathic.

However, complications in childbirth, which are detected in the labor room, are expensive to both parties (the mother and the doctors), as they influence the future maternal life of the woman, the child's condition and the extent of legal liability for the medical staff. Generally, a woman includes in her story medical terminology defining the cause of the complications (as doctors called it: "clinically narrow pelvis", "weak labor activity", "double entwining", etc.), but the semantic development of this line in narratives becomes the experience of responsibility and guilt, as well as their distribution between the actors of childbirth. ${ }^{11}$

According to the law in Russia, a woman must give written consent for any medical procedures. This often happens in an environment of psychological pressure and, in fact, lack of full-fledged choice, because the woman in labor is afraid of pain and cannot adequately assess all the consequences of her actions. Aggression on the part of doctors can be explained by the wish to protect the interests of the child, but the mother is forced to take the blame for the harm caused to the baby (Mashinova 2020). 
However, it would be wrong to assume that repressive mechanisms are supported only by the medical community. The problem is systemic and rooted in Russian society as a whole, as evidenced by the texts generated by women. Similar social mechanisms work inside the maternity hospital, which have already been noted in other closed systems: the army, boarding schools, prison, etc. Verbal and behavioral repression may be habitual and not reflexive, but it is easily recognized in the text. Here is a typical example where a woman is the object of manipulation, being in the position of a punished child who has to seek permission for any action:

I was dying to get up and walk around. I called the nurse. She gave me permission. I walked around for about ten minutes, it helped a little. Then a different nurse came in and started yelling at me, made me get back in bed and connected me to that apparatus again. I had a strong urge to push, but they wouldn't allow it. They said the head had to crown first. Don't move, just breathe. I begged someone, anyone, to stay with me, but to no avail. At that point, I put my hand down there and realized I was touching the head of my baby! I start to panic. I yell, the head is coming out! The team comes running in, someone yells at me for making a mess by spilling water on the table. (Evgeniia 2012)

In general, the repetition of the rapport "ask - not allowed", "did - scolded, praised" is one of the most frequent mechanisms of a text about childbirth. In the analyzed cases, most informants allow themselves to be treated in this way, because such relationships are not unique and all those who have passed elementary educational institutions are familiar with and adapted to them; the repressiveness is recorded almost without value, simply as a fact of reality.

\section{Delivery room: Return to cooperation}

So, the most dramatic moments of the narratives are over; what is the final part of the birth remembered for? The pain does not go away, on the contrary, the sense of inevitability of disaster increases:

I thought about what I would compare my experience to-it's like you are going to pop a melon. And you totally understand that it's not possible, not even a little... And most importantly, it's like no one understands your problem, like you are completely alone with your feelings - feelings of complete helplessness. (Gorlova 2017) 
However, at this stage, attempts require coordinated work of women and the medical staff. Women report that it is at this stage of delivery that control is once again given back to them: "Here you are completely responsible for the birthing process of your child" (Marchenkova n.d.). The woman finally feels the child is again the goal for which she came to hospital.

I squatted down on my haunches and continued to push even harder. It was like coming to the end of a long-distance cross-country race. When you have very little strength left, and every bone in your body is hurting, but the goal is so close, you're almost there! (Olga 2001)

The transition to the delivery room means the end of the process is close at hand, and therefore is colored with positive emotions. The asceticism of the situation does not frighten them; cultural memory kicks in at this point, offering stereotypical knowledge of traditional places of birth: "Now I understand how our ancestors gave birth in the fields or in the bathhouse - at that point, you don't care where you are or who's around you" (Olga 2001). It is interesting that women often note the everyday nature of the 'last march' to the maternity chair (in flip-flops). Most likely, in this consistent detail of collective memory, the principle of contrast works: most women still remember the scope of the wedding and the special care of relatives during pregnancy. But in the gateway to motherhood, you have to walk in dressed in a washed-out hospital shirt on half-bent legs, clutching your stomach instead of riding in a troika sleigh with bells jingling.

I finally heard the long-awaited announcement... We're going to the delivery room...!!!!!!!!!! and I waddled like a penguin... I felt my baby between my legs... and I was so scared to make any false move ... was very proud of myself, because no one had to carry me, or even help me ... I made it there all by myself and got up on the chair of torture. (Calypso 2010)

The transition to the delivery room is not only a sign that the hard work is coming to an end, culminating in meeting the newborn, but also a place of cooperation between the woman and the team of doctors, returning the woman in labor to the center of attention.

The midwife commanded me to push during the contraction, but I didn't feel them. Then the doctor and I decided she would lightly tap on my stomach with her finger as a sign that it was time to push. Fortunately, the doctor didn't need to tap for very long; I gave birth to my son at 21:45 after just three pushes. (Matiz 2015) 
It is in this part of the memoirs that the collective 'we' appears, including the woman in labor and the doctors, and often the child:

There were four people around me and, as a team, we started to give birth together ... The only thing I did wrong - was suddenly laying down, when a contraction was over. But the attentive eye of the doctor noticed my oversight and we quickly corrected the situation. (Chemyakina 2009)

Once in the chair, only a few minutes away from the happiness of meeting her own child, women remember the scolding of doctors during labor almost without malice, although, according to those who have given birth and even their husbands, the woman is often berated here: "I didn't even feel when my baby was coming out, I thought that he hadn't even crowned yet, but they keep that from you and just berate you saying you don't really want to deliver your baby" (Ismailova 2012).

The story about the delivery can be accompanied by comical moments (wet the doctor, mother, etc.), serving as a discharge of the previous tension. The behavior of a woman in labor is often verbally evaluated by obstetricians, and then rewards follow (“They praised me for my strength (I didn't scream not even once) and my positive attitude ... Later they rolled me over to the telephone at the nurse's station and let me call Sasha and mama" (Olga 2001)), or punishment ("The midwife told me she wasn't going to put my son on my stomach because he was tired from being born because his mama couldn't even deliver a baby right" (Marchenkova n.d.)). The priority of medical procedures over the desire and right of the mother to feel physical intimacy with the child at this moment is generally recognized by new mothers who are satisfied with the moments when they are shown the child or allowed to put it to the breast. ${ }^{12}$

The woman here is often in a state of euphoria, overwhelmed by tears of joy and gratitude to doctors and midwives:

They brought him to me, showed him to me. Oooh! It's such a miracle, a real miracle, I wanted to burst into tears of joy and happiness, but because of my state of shock, the tears didn't come for some reason. Because my head was spinning from the shock, I begin talking nonsense, saying the doctors were saints, thank you so much. Finally an elderly lady scolded me: lady, stop acting like that. (Marchenkova n.d.)

According to the law of the emotional pendulum, the one who holds back from crying out in pain also wants to repress the tears.

The delivery of the afterbirth is recorded in narratives as an option; it is mentioned only in passing when discussing how relatives are notified about the birth of the baby. 
The final point of communication between the medical staff and the woman is a ritual question: "Will you come back for a second child?" The answers from the same woman often differ depending on what stage of the process she is asked. For instance, while in the birthing chair, her answer contrasts to her answer after the birth. Her answers are expressed sharply like "No way!", "only caesarean", "let my husband come for the second one", while these fresh impressions change after weeks, months, and years to "certainly". This change of position is more than understandable, but the very rituality of the question is interesting to interpret. Perhaps, on the part of doctors, this is a ritualized sign of feedback, which completes the initiation by returning to the normative, dialog mode of the woman and obstetricians. It is significant that any response is considered acceptable: a negative one increases the value of the child gained through suffering, while a positive one eliminates all the negative experiences of childbirth, including the pain and rudeness of the staff.

\section{Postnatal ward: Instructing young people as a narrative coda}

It is interesting to mark that there are surprisingly few descriptions of the first impression of a newborn in the birth narratives, and it is clear that the focus of the narrator and the audience is not on the baby (cf. Marander-Eklund 2020). The impressions are rather a continuation of the evidence of the altered state of the participants in the process:

They brought me my boy. My first reaction: he's ugly, ruddy, swollen, bald, with some kind of thick balm on his eyes ... And I couldn't for the life of me remember his length and weight, I asked several times, and finally wrote it in my phone. Later, in the postnatal unit, I found that information on his medical bracelet and laughed that I didn't think to look at the cheat sheet. (Matiz 2015)

The cadence of the narrative is giving a formula for their readers to follow if/ when they give birth. From brief: "Girls, give birth, don't be afraid! Good luck to everyone" to the expanded and paradoxical:

While I was in hospital to give birth, I tried to remember how painful it was, because I had heard that you forget the pain and you want to give birth again. But I didn't want to repeat that experience! ... In summary, ladies, it's very painful and scary giving birth, so you should do it! Because kids are a reward from the Lord, and there is no better gift than the gift of motherhood. The result of your giving birth is so great and precious, 
and worth the sacrifice even more than days of pain and exhaustion. (Ismailova 2012)

In the context of internet sources, this information is a confirmation of the mother's initiation, the essence of which is to overcome pain and fear.

Ladies, it was so painful... indescribable pain... and when I called my husband, I told him if he wanted a daughter, he would have to give birth himself. I pass... P.S. After almost 9 months... I want another baby and I'm scared. (Calypso 2010)

\section{CONCLUSION}

As it has been for centuries, childbirth is one of the most important episodes in a person's biography. The vast majority of texts about second births begin with the moment of reflection on the first, and the duration of the pregnancy is devoted to finding the optimal conditions for a particular woman for the next birth. That is why the analysis of 'unprepared' first acts of childbirth should precede further research on alternative childbirth practices, because they are called natural, in fact, secondary in choice and marginal in quantity, in opposition to the generally accepted practice of childbirth in hospital.

In addition, birth narratives become the texts that are constantly present in every culture, thanks to the interactivity of Web 2.0, available to a huge number of users. These narratives speak about being in an altered state of consciousness and returning to the 'normal world'. In these autobiographical narratives, authors often use the possibilities of active compensatory subjectivity provided by the very act of creating a text. Requests from the readers (determined through the reactions of commenters) vary depending on their status. For those who have not yet given birth, it is important to translate cognitively learned concepts into language representations:

I'm afraid of giving birth and that's all I can think about all day ... Ladies, what does a contraction feel like? What about pushing? Of course, everyone has a different experience, but maybe it will help me to be a little less panicked. (Petrukhnova 2020)

This language is constantly in need of updating, and although it is very difficult to describe labor pain and other physiological processes in a new way (the narratives are formed discursively), it is popular for the audience to request fresh stories: "I'm laughing after every your sentence; for those who are afraid 
to give birth, maybe they should read your article. Their fear will vanish right away.)))) Could anyone write about caesarean in the same way" (comments to Calypso 2010). Overcoming the fear of the inevitable is one of the main motivating factors of the popularity of such texts.

According to the authors, during pregnancy they used several sources of information to raise their awareness and reduce anxiety, such as literature, forums, and personal experiences of past births. These searches often become the reference points that women rely on to form their own narrative, especially its final, analytical part. In this sense, I can conclude that narratives about childbirth are not alien to the research intention - to write a text that they themselves would like to read when they are pregnant - now this knowledge is obtained by them in their own unique experience:

I'm asking myself these questions:

- Is labor really painful?

- Yes, but you'll survive.

- What if I look stupid or do something wrong?

- You're in such a state that you aren't even thinking about that.

- Is being a mom difficult?

- It's different at different times. It's pure joy, but also around the clock without days off or even a lunchbreak:)

- If I knew how difficult it was, would I do it again?

- YES! Because, beyond exhaustion, looking terrible, and other issues, there's this huge plus ...LOVE. The love that inevitably comes into the life of any mother. (Elisaveta777 2015)

Didactic endings are less common. They occur as a specific recommendation: "I want to give you ladies some advice. No matter how painful it gets, try not to lose your head. Listen to the midwife and the doctor. Read as much as you can about childbirth, so that you will be ready at least a bit" (Anonymous 2020), and generically didactic in character: "I know for sure that I'm ready to give birth again, if necessary. You'll live through it. My baby has grown now and I'm pregnant with our second one. We're doing wonderfully. But that's because we all respect each other..." (Nastia 2019).

Although the story of childbirth is most often posted on the websites of forums for women, it can also be designed as an appeal to the newborn and, in this case, asserts the uniqueness of the child's connection with the mother:

I dedicate my story to you, my little hero, who has changed my life forever ... We will discover the world together. But most important is that we have 
each other. And I'll be the only one who will know you 9 months longer than anyone else. (maksimka13 2015)

Especially appreciated (by both pregnant women and those who have already given birth) are the practices of overcoming the ordeal of childbirth, fighting fear and anxiety. Among them, as I have already noted, is a strong subjective position (granted if not by reality, then by discourse), a statement of the value of the experience as a unique one. A kind of repressive and censoring mechanism works within the community (this relates to the state of Russian society as a whole). This censorship manifests itself as a reaction to comments related to evidence of rudeness and incompetence of the medical staff, confessions of a lack of maternal love, etc., with aggressive condemnation, which, in my view, indicates a powerful demand not for the truth, but for overcoming fear.

A sense of humor becomes a lifesaver, hotly demanded by the audience. Leaving a woman in the hours of labor pain, it returns to her in the story of the experience, becoming a means of strengthening the author's position. At the same time, the comedy also touches on the 'holy of holies' - the newborn, whose acquaintance becomes the main intrigue of the future motherhood:

They laid this little blue Avatar on my breast - he quieted and you couldn't hear him breathing; I asked if he was alive, the doctor smiled ... But he's like having been colored with a blue marker, a bruise on his head - from drilling his way out of me, a big bruise on the bridge of his nose because I couldn't get his nose out for a long time - but he's still truly the most beautiful baby to me, and very manly. (bjbj2 n.d.)

In conclusion, I would like to remind you that such a contingent, the first-time young expectant mother, is the most compliant in its interaction with the system and its representatives. Any complication and aggravation of introductory procedures, such as having many children, a second or third caesarean section, the age of a woman, the presence of chronic or detected diseases during pregnancy, for example, dramatically increases the repressiveness of the system at every stage from the consultation to the maternity ward. However, the analyses of the narratives of complications during childbirth deserve a separate article.

Translated by Dana Evans and Konstantin Tsibizov 


\section{ACKNOWLEDGEMENTS}

The study was supported by a grant from the Russian Science Foundation (project No. 19-18-00221), and proofread by Dana Evans.

\section{NOTES}

1 A complete survey of literature, except for titles published in the most recent decade, is available in the article by Carolyn Sargent and Lauren Gulbas (2011).

2 The topic of aggressiveness in the perinatal culture is gaining a large following in mass media: for example, a specialized community Violence in Birth has existed on the Russian social network InContact (VK) since 2016, currently containing about 500 messages (see https://vk.com/humanize_birth, last accessed on 8 October 2020).

${ }^{3}$ Narratives of childbirth have a common structure. However, not all narratives contain all positions of the virtual supertext I have distinguished. Due to that, of about 300 total analyzed narratives, I adduce here only the most illustrative texts. Meaningful omissions of positions in some narratives are stipulated specifically.

4 Visual impressions in the materials are specifically not accented by women; yet, in a narrative of a home birth, they are significant, often reaching ekphrasises.

5 With this self-perception, the health problems of a pregnant woman are described in the mode of disidentification with the body (Matiz 2015). In general, in narratives about childbirth, everything that remains without visible consequences for the child, most often fits into a short list: "There were so many problems - with the right kidney, a short cervix, colds, conjunctivitis, insomnia, and the crowning moment, terrible hemorrhoids (three days before birth). I don't even remember all of it anymore" (Elisaveta777 2015).

${ }^{6}$ Cf. the perception of the admission into the maternity ward as a symbolic border, and the midwife as a guard in Finnish stories about childbirth (Marander-Eklund 2020).

7 For other functions and meanings of pain, see also Belousova 1998.

8 Ekaterina Belousova considers doctors as a collective hero in the function of assistant, uniting doctors of all specialties, midwives, and nurses (Belousova 1999), but I tend to differentiate the roles of the medical staff, following the authors of the stories.

9 Further biography of this woman includes cleaning without anesthesia, when the nurse claps her hand over the patient's mouth, damaged veins on both hands from intravenous drips... and the conclusion: "In general, I do not want to give birth anymore. They say I'll forget everything. My son is almost six years old, and I remember every detail" (Kukusikii 2019). The request to overcome fear, rather than the 'truth' on sites with birth stories, is rationalized, in my opinion, by aggressive responses to such stories: "Why do I need this information? I gave birth easily. No lacerations, no 
blood loss. Everything is fine. And now what? Do I need to tell the whole world about it?" (Marusya84 in comment to Kukusikii 2019).

${ }^{10}$ It is this change in the relationship style that characterizes the degree of pain and confusion more than the actual rudeness of the staff demonstrated in this dialogue:

'Oh, my God, do something, do something for the pain'.

'No... It's too late.'

'Give me a C-section.'

'You're a fool, you'll give birth yourself...' (Calypso 2010).

${ }^{11}$ It is the shifting of all responsibility to the mother that becomes an introductory motivating block in the narratives of supporters of a natural childbirth: women recount their dialogues with doctors, in which they see the reluctance of doctors to share responsibility for the course of childbirth and the health of the child.

${ }^{12}$ In the repression that persists in the Russian maternity system, there are several layers: from the common practice of childbirth in a chair, lying on the back, a pose convenient for doctors, to the inclusion of maternity hospitals in the health system (Soviet in origin) basing its activities on the doctrine that the doctor as a professional is more valuable, making the patient (as an amateur) of secondary value. All this converts childbirth from the main event in the life of the family into one of the conveyor operations of the medical institution, where the result is evaluated by issuing a product - a newborn - regardless of what the woman endures within the walls of the maternity hospital.

\section{INTERNET SOURCES}

https://www.7ya.ru/pub/birthRussia/, last accessed on 28 September 2020. http://deti.mail.ru/birthstories/, last accessed on 28 September 2020.

http://www.kid.ru/forum/index.php?showforum=9, last accessed on 28 September 2020. https://www.kemdetki.ru/biblio/stories/, last accessed on 28 September 2020.

https://vk.com/moi_rodi, last accessed on 28 September 2020.

Akishina, Irina 2005. Glavnoe - sootvetstvuiushchii nastroi. [The Main Thing Is the Appropriate Motivation.] 7ya.ru, 25 May. Available at http://www.7ya.ru/article/ Glavnoe-sootvetstvuyuwij-nastroj/, last accessed on 24 September 2020.

Anonymous 2020. Vot i nastala pora napisat' mne svoiu istoriiu rodov. [Now It's Time to Write My Birthing History.] Vk.com, 26 June. Available at https://vk.com/ moi_rodi?w=wall-80494791_13690, last accessed on 25 September 2020.

bjbj2 n.d. Rody prikhodiat obychno neozhidanno. [Childbirth Usually Comes Unexpectedly.] Kemdetki.ru. Available at https://www.kemdetki.ru/biblio/ stories/490/, last accessed on 24 September 2020.

Calypso 2010. Kak ia rozhala nedeliu! [How I Gave Birth a Week!] Kemdetki.ru. Available at https://www.kemdetki.ru/biblio/stories/7103/, last accessed on 24 September 2020 . 
Chemyakina, Cveta 2009. Samyi schastlivyi den' - piatnitsa, 13-e. [The Happiest Day Is Friday the 13th.] 7ya.ru, 1 July. Available at https://www.7ya.ru/article/Samyjschastlivyj-den-pyatnica-13-e/, last accessed on 25 September 2020.

Elena 2007. Rody: Komediino-eroticheskii triller. [Childbirth: A Comedy-erotic Thriller.] 7ya.ru, 13 February. Available at http://www.7ya.ru/article/Rody-Komedijnojeroticheskij-triller-Chast-1/, last accessed on 24 September 2020.

Elisaveta777 2015. Rozhdenie nashego angelochka. [The Birth of Our Little Angel.] Kemdetki.ru. Available at https://www.kemdetki.ru/biblio/stories/1071/, last accessed on 24 September 2020.

Evgeniia 2012. Beremennost' dlinoi 42 nedeli i rody za 10 chasov. [A 42-week Pregnancy and Birthing in 10 Hours.] 7ya.ru, 17 November. Available at http://www.7ya. ru/article/Beremennost-dlinoj-42-nedeli-i-rody-za-10-chasov/, last accessed on 24 September 2020.

Gorlova, Anetta 2017. Rody 15 chasov - ad i rai v odnom flakone! [Childbirth 15 Hours Hell and Heaven in One Bottle!] 7ya.ru, 5 November. Available at https:// www.7ya.ru/article/Rody-15-chasov-ad-i-raj-v-odnom-flakone/\#null, last accessed on 25 September 2020.

Ismailova, Nina 2012. Vse ravno eta bol' zabyvaetsia. [All the Same, This Pain Will Be Forgotten.] 7ya.ru, 22 January. Available at https://www.7ya.ru/article/Vseravno-jeta-bol-zabyvaetsya/, last accessed on 25 September 2020.

Jane 2006. Dolgii rasskaz o dolgikh rodakh. [A Long Story about a Long Birth.] Materinstvo.ru, 27 September. Available at https://materinstvo.ru/art/436, last accessed on 24 September 2020.

Kasparova, Iuliia 2002. S chego nachinaetsia zdorov'e. [What Does Health Start from.] 7ya.ru, 10 October. Available at https://www.7ya.ru/article/S-chego-nachinaetsyazdorove-Chast-1-Beremennost/, last accessed on 25 September 2020.

Kozupitsa, Julia 2009. Moi pervye rody. [My First Childbirth.] Deti.mail.ru, 20 February. Available at http://deti.mail.ru/birthstories/15410/, last accessed on 24 September 2020 .

Kukusikii 2019. Kak ia rozhala. 10 iz 10. [How I Gave Birth. 10 out of 10.] Pikabu.ru, 17 April. Available at https://pikabu.ru/story/kak_ya_rozhala_10_iz_10_6650050, last accessed on 25 September 2020.

Liudmila n.d. Rasskaz o pervykh rodakh. [A Story about the First Birth.] Homestead. narod.ru. Available at http://www.homestead.narod.ru/birth.htm, last accessed on 25 September 2020.

maksimka13 2015. Moi 6 kg schast'ia. [My 6 kg of Happiness.] Kemdetki.ru. Available at https://www.kemdetki.ru/biblio/stories/1006/, last accessed on 25 September 2020.

Marchenkova, Oksana n.d. Kak ia rozhala synuliu. [How I Gave Birth to My Son.] Kid. ru. Available at http://www.kid.ru/pregnancy/index610.php3, last accessed on 24 September 2020.

Margo 2009. Pervyi sneg, pervye rody. [First Snow, First Birth.] 7ya.ru, 25 December. Available at http://www.7ya.ru/article/Pervyj-sneg-pervye-rody-11784/, last accessed on 24 September 2020. 
Marina 2008. Kak Ilian prishel v etot mir. [How Ilian Came to This World.] 7ya.ru, 30 January. Available at https://www.7ya.ru/article/Kak-Ilian-prishel-v-jetotmir-7939/, last accessed on 24 September 2020.

Mashinova, Maria 2020. Mnogo bukv. [Lots of Letters.] Vk.com, 24 May. Available at https://vk.com/moi_rodi?w=wall-80494791_13376, last accessed on 24 September 2020.

Matiz 2015. Vse po planu. [All According to Plan.] Kemdetki.ru. Available at https:// www.kemdetki.ru/biblio/stories/8965/, last accessed on 24 September 2020.

Nastia 2019. Kak ia rozhala. [How I Gave Birth.] Myslo.ru, 9 October. Available at https://myslo.ru/club/blog/kurilka/8xvw795mokGJac_SeVU9aw, last accessed on 24 September 2020.

Oksana 2005. Moi vertikal'nye rody na stule. [My Vertical Childbirth on a Chair.] 7ya. ru, 28 September. Available at https://www.7ya.ru/article/Moi-vertikalnye-rodyna-stule/, last accessed on 24 September 2020.

Olga 2001. Rodit' po-russki. [Giving a Birth in a Russian Way.] Sanikate.narod.ru, 2 November. Available at http://sanikate.narod.ru/birth1.htm, last accessed on 24 September 2020.

Petrukhnova, Anastasiia 2020. Boius' rozhat'. [I'm Afraid to Give Birth.] Vk.com, 17 June. Available at https://vk.com/moi_rodi?w=wall-80494791_13520, last accessed on 25 September 2020.

Shepka n.d. Malen'kii komochek schast'ia, ili schastlivoe chislo dnia rozhdeniia. [A Small Lump of Happiness, or a Happy Birthday Number.] Kemdetki.ru. Available at https://www.kemdetki.ru/biblio/stories/1082/, last accessed on 24 September 2020.

Zlato-serebro 2009. Esli komu interesno... [If Anyone Is Interested...] Deti.mail.ru, 20 February. Available at https://deti.mail.ru/birthstories/15403/, last accessed on 24 September 2020.

\section{REFERENCES}

Belousova, Ekaterina 1998. Rodovaia bol' v antropologicheskoi perspektive. [Birthing Pain in an Anthropological Perspective.] Arbor mundi, No. 6, pp. 48-57. Available at http://www.ruthenia.ru/folklore/belousova1.htm, last accessed on 25 September 2020 .

Belousova, Ekaterina 1999. Predstavleniia $i$ verovaniia, sviazannye s rozhdeniem rebenka: sovremennaia gorodskaia kul'tura. Avtoreferat dissertatsii na soiskanie uchenoi stepeni kandidata kul'turologii. [Ideas and Beliefs Related to the Birth of a Child: Modern Urban Culture. Abstract of the Dissertation for the Degree of Candidate of Cultural Studies.] Moscow: Rossiiskii gosudarstvennyi gumanitarnyi universitet. Available at http://www.ruthenia.ru/folklore/belousova5.htm, last accessed on 25 September 2020.

Jordan, Brigitte 1978. Birth in Four Cultures. A Crosscultural Investigation of Childbirth in Yucatan, Holland, Sweden, and the United States. Montreal: Eden Press Women's Publications. 
Kay, Margarita Artschwager (ed.) 1982. Anthropology of Human Birth. Philadelphia: F.A. Davis. Available at https://archive.org/details/anthropologyofhu0000unse, last accessed on 25 September 2020.

Kuksa, Tatiana 2019. Teoreticheskie podkhody k issledovaniiu praktik rodovspomozheniia i tekstov o rodakh. [Theoretical Approaches to Obstetric Practices Studies and Texts about Childbirth.] Meditsinskaia antropologiia i bioetika, Vol. 17, No. 1, pp. 168-200. http://doi.org/10.33876/2224-9680/2019-1-17/08.

MacCormack, Carol P. (ed.) 1982. Ethnography of Fertility and Birth. London \& New York: Academic Press.

Marander-Eklund, Lena 2020. The Birth of a Child Experienced and Narrated in the 1990s Finland. Folklore: Electronic Journal of Folklore, Vol. 80, pp. 125-150. https://doi.org/10.7592/FEJF2020.80.marander_eklund.

Mikhel', Dmitrii 2017. Meditsinskaia antropologiia: Uchebnoe posobie. [Medical Anthropology: A Handbook.] Moscow: Delo.

Mitsiuk, Natalia \& Pokusaeva, Vita 2016. Vedenie beremennosti v dorevoliutsionnoi Rossii: ot traditsionnykh praktik $\mathrm{k}$ meditsinskomu znaniiu. [Maintaining Pregnancy in Pre-Revolutionary Russia: From Traditional Practice to Medical Knowledge.] Vestnik Smolenskoi gosudarstvennoi meditsinskoi akademii, No. 2, pp. 85-94. Available at https://cyberleninka.ru/article/n/vedenie-beremennostiv-dorevolyutsionnoy-rossii-ot-traditsionnyh-praktik-k-meditsinskomu-znaniyu/ viewer, last accessed on 25 September 2020.

Mukhina, Zinara \& Pushkareva, Natalia 2012. Dorodovoi period i rody v zhizni krest'ianki poreformennoi Rossii (preimushchestvenno Tsentral'nykh gubernii). [Prenatal Period and Childbirth in the Life of a Peasant Woman in Post-reform Russia (Mainly in the Central Provinces).] Nauchnye vedomosti Belgorodskogo universiteta, Vol. 22, No. 7 (126), pp. 160-168. Available at https://cyberleninka. ru/article/n/dorodovoy-period-i-rody-v-zhizni-krestyanki-poreformennoy-rossiipreimuschestvenno-tsentralnyh-guberniy/viewer, last accessed on 28 September 2020 .

Nartova, Nadezhda 2016. Materinstvo v sovremennoi zapadnoi sotsiologicheskoi diskussii. [Motherhood in Contemporary Western Sociological Debate.] Zhenshchina $v$ rossiiskom obshchestve, No. 3 (80), pp. 39-53. https://doi.org/10.21064/ WinRS.2016.3.4.

Nekliudov, Sergei (ed.) 2001. Rodiny, deti, povitukhi v traditsiiakh narodnoi kul'tury. [Maternity Rite, Children, Midwives in the Traditions of Folk Culture.] Moscow: Rossiiskii gosudarstvennyi gumanitarnyi universitet. Available at https://www. booksite.ru/fulltext/rodiny/text.pdf, last accessed on 28 September 2020.

Olson, Laura J. \& Adonyeva, Svetlana 2012. The Worlds of Russian Village Women: Tradition, Transgression, Compromise. Madison: The University of Wisconsin Press.

Petrova, Elena 2009. Dve nedeli v roddome: ozhidanie i rody. [Two Weeks in the Hospital: Waiting and Birthing.] In: Elena Zdravomyslova \& Anna Temkina (eds.) Zdorov'e i doverie: gendernyi podkhod $k$ reproduktivnoi meditsine: sbornik statei. St. Petersburg: Izdatel'stvo Evropeiskogo universiteta v Sankt-Peterburge, pp. 344-368. 
Pushkareva, Natalia \& Mitsiuk, Natalia 2015. Gendernye razlichiia v vospriiatii rodovogo akta ( $\mathrm{k}$ istorii rossiiskoi dvorianskoi povsednevnosti kontsa XIX nachala XX v.). [Gender Differences in the Perception of the Childbirth Act (To the History of Russian Noble Everyday Life of the Late 19th - Early 20th Centuries).] Nauchnye vedomosti Belgorodskogo gosudarstvennogo universiteta. Seriia: Istoriia. Politologiia, No. 13 (210), pp. 133-141. Available at https:// cyberleninka.ru/article/n/gendernye-razlichiya-v-vospriyatii-rodovogo-akta-kistorii-rossiyskoy-dvoryanskoy-povsednevnosti-kontsa-xix-nachala-xx-v, last accessed on 28 September 2020.

Pushkareva, Natalia \& Mitsiuk, Natalia 2017. Rodovspomozhenie i kul'tura detorozhdeniia $\mathrm{v}$ noveishei zarubezhnoi istoriografii (1975-2015). [Culture of Childbirth and Obstetrics in Contemporary Western Historiography (1975-2015).] Etnograficheskoe obozrenie, No. 4, pp. 147-163. Available at http://journal.iea.ras. ru/archive/2010s/2017/no4/147.htm, last accessed on 28 September 2020.

Radzinski, Viktor 2017. Akusherskaia agressiia v. 2.0. [Obstetric Aggression V. 2.0.] Moscow: StatusPraesens.

Raynor, Rachel Lucia Judith 2005. Storied Beginnings: Description and Analysis of Internet Childbirth Narratives. Diss. (PhD Thesis). University of California. Available at https://search.proquest.com/openview/0c00aa19711da2d7a180 $7496863226 \mathrm{a} 1 / 1$ ?pq-origsite $=$ gscholar $\& \mathrm{cbl}=18750 \&$ diss $=y$, last accessed on 28 September 2020.

Sargent, Carolyn \& Gulbas, Lauren 2011. Situating Birth in the Anthropology of Reproduction. In: Merrill Singer \& Pamela I. Erickson (eds.). A Companion to Medical Anthropology. Chichester, West Sussex \& Malden, MA: Wiley-Blackwell, pp. 289-304. https://doi.org/10.1002/9781444395303.ch14.

Shchepanskaia, Tatiana 1999. Mifologiia sotsial'nykh institutov: rodovspomozhenie. [The Mythology of Social Institutions: Delivery Care.] In: Konstantin Bogdanov \& Aleksandr Panchenko (comps.) Mifologiia i povsednevnost': materialy nauchnoi konferentsii (Sankt-Peterburg, 24-26 fevralia 1999 goda). St. Petersburg: Institut russkoi literatury Rossiiskoi akademii nauk, Vol. 3, pp. 389-423. Available at http://www.poehaly.narod.ru/repr-1.htm, last accessed on 28 September 2020.

Toporov, Vladimir 1995 [1971]. Peterburg i "Peterburgskii tekst russkoi literatury" (Vvedenie v temu). [St. Petersburg and "St. Petersburg Text of Russian Literature" (Introduction to the Topic).] In: Vladimir Toporov. Mif. Ritual. Simvol. Obraz. Issledovaniia v oblasti mifopoeticheskogo: Izbrannoe. Moscow: Progress - Kul'tura, pp. 259-367. Available at http://biblio.imli.ru/images/abook/folklor/Toporov_V.N. Mif._Ritual._Obraz._Simvol._1995..pdf, last accessed on 28 September 2020.

Trevathan, Wenda R. 1987. Human Birth: An Evolutionary Perspective (Foundations of Human Behavior). New York: Aldine De Gruyter.

Zdravomyslova, Elena \& Temkina, Anna (eds.) 2009. Zdorov'e $i$ doverie: gendernyi podkhod k reproduktivnoi meditsine: sbornik statei. [Health and Trust: A Gender Approach to Reproductive Medicine: A Collection of Articles.] St. Petersburg: Izdatel'stvo Evropeiskogo universiteta v Sankt-Peterburge. 
Natalia Gramatchikova $(\mathrm{PhD})$ is Senior Research Fellow at the Center of History of Literature at the Institute of History and Archeology of the Ural Branch of the Russian Academy of Sciences, Russia. Her main research areas are autobiographies, ego-documents, familial and historical memory, history of Ural literature and periodicals.

n.gramatchikova@gmail.com 